\title{
Development of New Efficient Synthetic Methods for Docetaxel
}

\author{
Jae Ho Heo, Sung Jun Park, J Joo Hi Kang, In Suk Lee, Jin Seo Lee, ${ }^{\dagger}$ \\ Young Jun Park, Kyoung Soo Kim, ${ }^{+*}$ and Jae Yeol Lee ${ }^{\star}$ \\ Research Institute for Basic Sciences and Department of Chemistrv. College of Sciences, \\ Kutng Hee Lnversity; Seoul 130-701, Korea. E-mail: lilakhtackr \\ †Chrogenix Co. Ltd., Kowoon Institute of Technologv Innowation, Stwon Lniversity, Whasung, \\ Kvinggi $+45-7+3$. Korea. 'E-mail. kshimpcóchirogenix.com \\ Recerved October 29, 2008, Accepted Kovember 20,2008
}

Key Words: Docetaxel, Phenylisoserine, 10-DAB III

Docetaxel is a clinically' well established anti-mitotic chemotherapy medication used mainly for the treatment of breast. ovarian. and non-small cell lung cancer. ${ }^{1.2}$ Docetaxel is considered better than doxorubicin. paclitaxel and fluorouracil as a cytotoxic antimicrotubule agent (Figure 1). ${ }^{1}$ Docetaxel is marketed worldwide under the name of Taxotere ${ }^{k}$ by SanofiAventis. ${ }^{3}$ Docetaxel is of the chemotherapy drug class (taxane) and is a semi-sy'nthetic analogue of paclitaxel $\left(\mathrm{Tavol}^{\mathrm{B}}\right.$ ). an extract from the rare Pacific yew tree Taxus brevifolia. ${ }^{2}$ As shown in Figure 1, docetaxel differs from paclitaxel at two positions in its chemical structure: (1) It has a hydroxyl functional group on carbon-10. whereas paclitaxel has an acetate ester. (2) a tert-butyloxylcarbonyl group exists on the nitrogen atom of phenylpropionate side chain rather than benzoyl group. The carbon-10 functional group change causes docetaxel to be more water soluble than paclitaxel. ${ }^{2}$ However, great difficulty exists in the total synthesis of docetaxel because of its complex structure. Since 10-deacetyl baccatin III (10-DAB III) was extracted in large scale from the renewable and readily available European yew tree Taxus baccata, ${ }^{4}$ however the effective semi-sy nthesis of docetaxel was started to reduce synthetic difficulty and cost of docetavel dramatically.

As a result. a number of semi-sy'nthetic methods for docetavel have been reported up to date. ${ }^{\text {E-15 }}$ Among them, the method comprised of the coupling reaction of 10 -deacetylbaccatin III (10-DAB III) with commercially available ( $2 R$. 3S)-phenylisoserine seems to be an effective and cheap way to synthesize docetaxel. in particular. for large-scale conmercial production. ${ }^{16}$ Herein. we describe the efficient synthetic methods of docetaxel for large scale-up preparation by using new protecting groups and a mild de-protecting condition.

After a number of trials. we decided to protect both $\mathrm{C}-3{ }^{\prime} \mathrm{NH}_{2}$ and $\mathrm{C}-2^{\circ} \mathrm{OH}$ groups of ( $2 R, 35$ )-pheny lisoserine (1) with 1,1-dichloroacetone or chloral ethylate in the presence of PPTS to

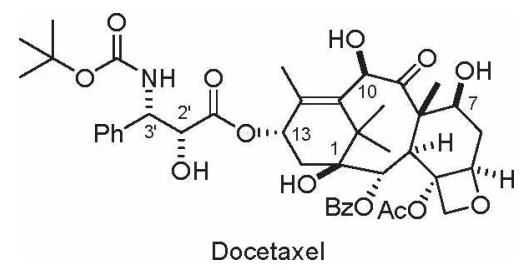

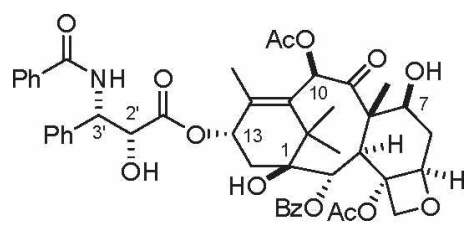

Paclitaxel

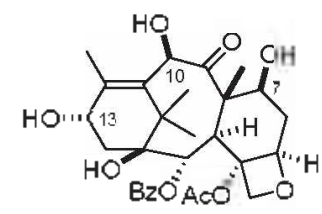

10-DAB |I|

Figure 1. Structures of docetaxel, paclitaxel, and 10-DAB III<smiles>COC(=O)[C@H](O)[C@H](N)c1ccccc1</smiles>

2a: $\mathbf{R}^{1}=\mathrm{CH}_{3}, \mathrm{R}^{2}=\mathrm{CHCl}_{2}(95 \%)$ $2 \mathrm{~b}: \mathrm{R}^{1}=\mathrm{H}, \quad \mathbf{R}^{2}=\mathrm{CCl}_{3}(95 \%)$

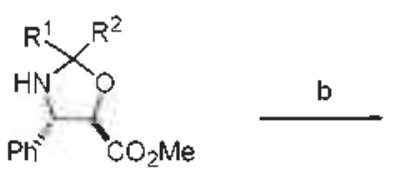

3a. $R^{1}=\mathrm{CH}_{3} \cdot \mathrm{R}^{2}=\mathrm{CHCl}_{2}, \mathrm{R}^{3}=\mathrm{N}^{+}(\mathrm{E})_{3} \mathrm{H}(85 \%)$

3b. $R^{1}=H \quad R^{2}=\mathrm{CCl}_{3}, \quad R^{3}=\mathrm{H}(85 \%)$

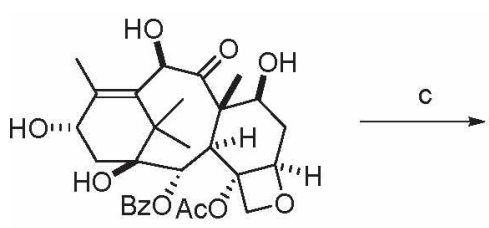

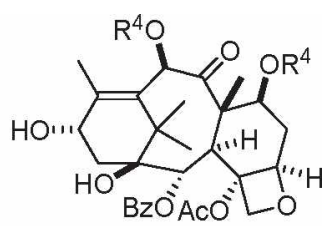

5a. $R^{4}=\mathrm{COCBr}_{3}(93 \%)$ 5b. $R^{4}=\mathrm{CO}_{2} \mathrm{CH}_{2} \mathrm{CH}=\mathrm{CH}_{2}\langle 95 \%)$

Scheme 1. Reagents and conditions: (a) $\mathrm{CH}_{2} \mathrm{COCHCl}_{2}$ ( tor 2a) or $\mathrm{CCl}_{3} \mathrm{CH}(\mathrm{OH}) \mathrm{OEt}$ (tor $2 \mathrm{~b}$ ), PPTS, toluene, reflux, $3 \mathrm{~h}$; (b) $3 \mathrm{~N} \mathrm{LiOH}, \mathrm{MeOH}, \mathrm{rt}$, $30 \mathrm{~min}$, then $3 \mathrm{~N} \mathrm{HCl}$ (for $3 \mathbf{b}$ ) and $\mathrm{Et}{ }_{3} \mathrm{~N}$ (for $3 \mathrm{a}$ ); (c) $\mathrm{CBr}_{2} \mathrm{COCl}$ ( for $5 \mathrm{a}$ ) or $\mathrm{ClCO}_{2} \mathrm{CH}_{2} \mathrm{CH}=\mathrm{CH}_{2}$ (for $5 \mathrm{~b}$ ), pyridine, $\mathrm{CHCl}_{3}, 0^{\circ} \mathrm{C}$ to $\mathrm{rt}, 3 \mathrm{~h}$. 

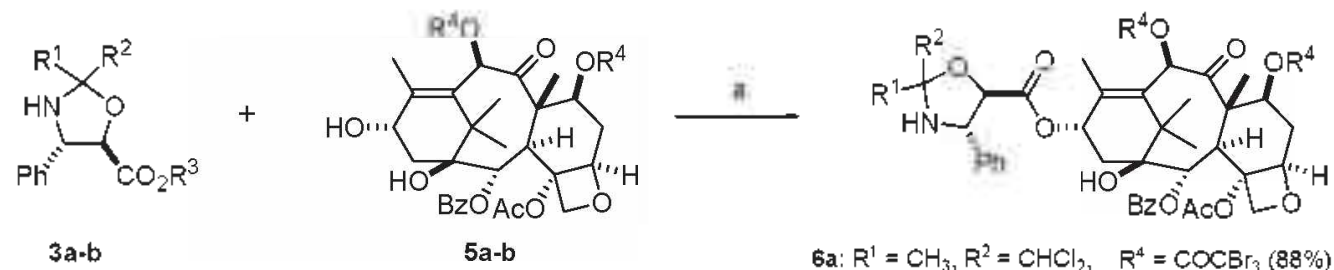

Ga: $\mathrm{R}^{1}=\mathrm{CH}_{3}, \mathrm{R}^{2}=\mathrm{CHCl}_{2}, \quad \mathrm{R}^{4}=\mathrm{COCB}_{3}(88 \%)$

6b: $R^{1}=\mathrm{CH}_{3}, \mathrm{R}^{2}=\mathrm{CHCl}_{2}, \quad \mathrm{R}^{4}=\mathrm{CO}_{2} \mathrm{CH}_{2} \mathrm{CH}=\mathrm{CH}_{2}(88 \%)$

6c: $\mathrm{R}^{1}=\mathrm{H}, \quad \mathrm{R}^{2}=\mathrm{CCl}_{31} \quad \mathrm{R}^{4}=\mathrm{COCB}_{3}(85 \%)$

Ed: $R^{1}=H_{1} \quad R^{2}=\mathrm{CCl}_{3}, \quad R^{4}=\mathrm{CO}_{2} \mathrm{CH}_{2} \mathrm{CH}=\mathrm{CH}_{2}(92 \%)$
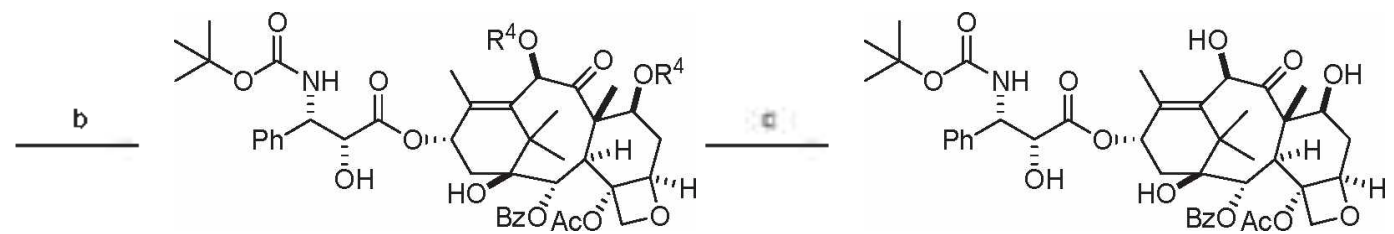

7a: $R^{4}=\mathrm{COCBr}_{3}$

7b: $\mathrm{R}^{4}=\mathrm{CO}_{2} \mathrm{CH}_{2} \mathrm{CH}=\mathrm{CH}_{2}$

Docetaxel

Scheme 2. Reagents and conditions: (a) DCC, DMAP, toluene/DMF, $0^{\circ} \mathrm{C}$ to $\mathrm{rt}, 3 \mathrm{~h}$. (b) $\mathrm{cHCl}$, EtOAc, rt, $20 \mathrm{~min}$ to $12 \mathrm{~h}$, then $\mathrm{NaHCO}$, and $\left({ }^{\mathrm{t}} \mathrm{Boc}\right)_{2} \mathrm{O}, \mathrm{rt}, 2.5-3 \mathrm{~h} ;$ (c) see Table 1.

Table 1. Yield of compond 7, reaction condition $\mathrm{e}$ in Scheme 2 , and its yield

\begin{tabular}{|c|c|c|c|c|}
\hline Entry & Compound & Yield (\%) of 7 & Reaction condition $\mathrm{c}$ & Yield $(\%)$ of docetasel \\
\hline l & $6 a$ & $7 \mathrm{a}^{a}$ & $\mathrm{AcONH}+\mathrm{MeOH} / \mathrm{THF}(1: 1), \mathrm{rt}, 3 \mathrm{~h}$ & $90^{\circ}$ \\
\hline 2 & $6 b$ & $7 b(95)$ & $\mathrm{Pd}\left(\mathrm{PPl}_{3}\right)_{4}$, aniline, $\mathrm{CH}_{2} \mathrm{Cl}_{2}$, rt, $30 \mathrm{~min}$ & 84 \\
\hline 3 & $6 c$ & $7 a(96)$ & $\mathrm{AcONH}_{4}, \mathrm{MeOH} / \mathrm{THF}(\mathrm{I}: 1), \mathrm{tt}, 3 \mathrm{~h}$ & 92 \\
\hline 4 & $6 \mathrm{~d}$ & $7 \mathrm{~b}(92)$ & $\mathrm{Pd} / \mathrm{C}, \mathrm{HCONH}_{4}, \mathrm{MeOH}, \mathrm{rt}, 40 \mathrm{~min}$ & 85 \\
\hline
\end{tabular}

${ }^{a}$ Not purified and used for next reaction. ${ }^{6}$ Two-step yield

afford the trans-oxazolidine intermediates $2 \mathbf{a}$ and $\mathbf{2 b}$ as a diastereomeric mixture in $95 \%$ yields. respectively. which were hydrolyzed with $3 \mathrm{~N} \mathrm{LiOH}$ and treated with $3 \mathrm{~N} \mathrm{HCl}$ to provide the corresponding carboxylic acids in $85 \%$ y ields. In the case of $3 \mathbf{a}$. the carbosylic acid was converted into triethylamine salt due to its low stability at room temperature (Scheme 1).

With respect to $10-\mathrm{DAB}(4)$, both hydroxyl groups of $\mathrm{C}-7$ and $\mathrm{C}-10$ were protected with tribromoacetyl chloride or allyl chloroformate in the presence of pyridine as a base to afford the corresponding 5a-b in 93 and $95 \%$ yields. respectively. Coupling of acid $\mathbf{3 a - b}$ with 7,10-diprotected baccatin III (5a-b) was carried out by using DCC and catalytic amount of DMAP as coupling reagents to afford $6 \mathrm{a}-\mathrm{d}$ in $85-92 \%$ yields via column chromatography and recrystallization. Treatment of 6a-d with $c-\mathrm{HCl}$ followed by the introduction of ${ }^{\prime} \mathrm{Boc}$ into $\mathrm{C}-3$ ' $\mathrm{NH}_{2}$ of phenylisoserine side chain provided the corresponding 7.10-diprotected docetavels 7 a-b in $92-96 \%$ yields. Finally. the removal of tribromoacetyl group with ammonium acetate or ally loxycarbonyl group with palladium cataly'st afforded the desired docetaxel in $84-92 \%$ yields (Scheme 2 ). The reaction conditions and their results were summarized in Table 1. The spectroscopic data of synthetic docetaxels were exactly coincided with those of authentic docetaxel.

In conclusion. we have developed new synthetic methods for docetaxel. especially for large scale-up process. By employing one methodology as follows: 1.1-dichloroacetone for pheny lisoserine tribromoacetyl chloride for 10-DAB III, and
$\mathrm{AcONH}_{4}$ for de-protection. the synthesis of $100 \mathrm{~g}$ of docetaxel has been carried out three times with an overall yield up to $60 \%$ and $99.4 \%$ purity for real scale-up study.

Acknowledgments. This work was supported by Ministry of Knowledge Economy (10026022-2006-01 \& 100260222007-02). Korea.

\section{References}

1. Lyseng-Williamson, K. A; Fenton, C. Drtgss 2005, 65, 2513.

2. Clarke. S. J.: Rivory. L. P. Chin. Phamacohinet. 1999, 36.99.

3. Guenard, D.; Gueritte-Voegelein, F; Potier, P. Acc. Chent Res. $1993,26,160$.

4. (a) Glowniak, K.: Mroczek, T.; Zobel, A. M. Phytomedicine 1999, 6, 135. (b) Suffness, M. In Am. Repts. Hed. Chem. Bristol, J. A., Ed, Academic Press: Sán Diego, CA., 1993; pp 305-314. (c) Kim, S.C.: Kim, H.-K. Bull Korean Chem. Soc. 2000, 21, 1047.

5. Didier, E.; Fouque, E. Tetwhedron Lett. 1994, 25, 2349.

6. Oi. C. M: Yang. L. C.: Wang, L. Y. Chin. J. Chem 2003, 21, 1536

7. Ojina, I.; Lin, S.: Chakravarty, S.J. Org. Chem 1998, 63, 1637.

8. Oi. C. M. Wang. L. Y: Yang. L. C. J. Heterocycl. Chent $2005,42,679$.

9. Naidu, R.: Foo, S. S. K. I. S. Patent 2008146824 Al, 2008

10. Naidu, R. L.S. Patent 2005272807 A I, 2005.

11. Naidu, R. PCT HO 2005082875 A2, 2005

12. Naidu, R. PCT HO $2008090368 \mathrm{Al}, 2008$

13. Liu, T. Cant. Patent 254995I Al, 2007.

14. Nikolakakis, A.; Haidara, K. Sauriol, F.; Maner, O.; Zamir, L. O. Bioolg. 1hed. Chem. 2003, 11, 1551 .

15. Vassilis, G. Curn. Hed. Chem, 2002, 9, 869

16. Lin, S.; Ojima, I. Expent Opin. Ther Pat. 2000, 10, 869 